\title{
Muutoksen kauppiaat ja liikkeenjohdolliset muodit
}

\author{
Janne Tienari
}

\begin{abstract}
Liikkeenjohdon konsultit ovat vuonna 2000 tärkeämpiä yhteiskunnallisia toimijoita kuin koskaan aikaisemmin. Konsultit luovat, muokkaavat ja levittävät tietoa. Konsultit ovat myös ottaneet kontolleen perinteisiä liikkeenjohtajien tehtäviä. Liikkeenjohdon konsultoinnin maailmanlaajuinen volyymi kasvoi lähes 20-kertaiseksi vuosien 1980 ja 1997 välillä. Kasvu jatkuu kiivaana uudella vuosituhannella. Mutta miten ja miksi liikkeenjohdolliset opit muuttuvat muodeiksi?
\end{abstract}

\begin{abstract}
Aikuiskasvatus -lehden teemanumerossa 1/1999 tartuttiin siis ajankohtaiseen aiheeseen. Myös suomalaisissa yrityksissä ja julkisen sektorin organisaatioissa työntekijät ovat yhä useammin tekemisissä erilaisten "ulkopuolisten neuvonantajien" kanssa. Aikuiset joutuvat kasvatettaviksi, vapaaehtoisesti tai vastoin tahtoaan.
\end{abstract}

Miksi konsultointi myy? Konsultointityö on ennen kaikkea muutoksen kylvämistä ja muuttamista. Muutos on näkökulmasta riippumatta tekijä, jonka pitäminen otsikoissa on kaikkien liikkeenjohdon konsultoinnin kentällä pelaavien edun mukaista. Konsultit välittävät merkityksiä ja luovat vanhoista palasista kokonaan uusia (Czarniawska-Joerges 1990). Konsultit ovat tiedon meklareita (Hargadon 1998) ja muutoksen kauppiaita (Tienari 1999; Ainamo ja Tienari 2000).
Konsultointi on ennen kaikkea liiketoimintaa. Erityisesti suurten kansainvälisten konsultointiyritysten toimintaan kuuluu oleellisena osana pyrkimys esiintyä liikkeenjohdollisten oppien, menetelmien ja käytäntöjen kehityksen keihäänkärkenä. Aina pitää olla tarjolla jotakin uutta. Samanaikaisesti vanhoista tuotteista, tai ainakin niiden nimikkeistä, pitää päästä jouhevasti eroon. Uusiutuminen on konsultoinnin keskeinen logiikka.

Konsultointi on myös yksinkertaistamisen taitoa. Konsulttien usein epämääräinen julkisuuskuva kiinnittyy nykyään selvimmin erilaisten "ismien" eli muodikkaiden liikkeenjohdollisten oppien kauppaamiseen ${ }^{1}$. Opit ja muodit kiinnittyvät nykyisin lähes poikkeuksetta muutokseen ja muuttamiseen. Ne kiinnittyvät erojen tekemiseen uuden ja vanhan välillä. 
Tässä artikkelissa esitetään näkökulmia siihen, miten ja miksi liikkeenjohdolliset opit muuntuvat muodeiksi. Artikkeli on katsaus aikaisempaan kirjallisuuteen. Erityisenä tarkastelun kohteena on konsulttien ${ }^{2}$ rooli oppien ja muotien kauppiaina. Artikkeli pyrkii näin tuomaan uuden vivahteen suomalaiseen keskusteluun aikuiskoulutuksesta ja -kasvatuksesta. Se tarjoaa myös liikkeenjohdollisten oppien potentiaalisten ostajien tulkittavaksi yhden viitekehyksen, jonka kautta tarkastella alan tarjontaa uteliaan kriittisesti.

\section{Liikkeenjohdolliset muodit}

Miksi 1980-luvun alkupuolella länsimaisissa yrityksissä ryhdyttiin puhumaan kulttuurista? Miksi 1990-luvulle tultaessa avainsana oli liiketoimintaprosessien uudistaminen? Miksi nykyisin kaikki kuuluvat puhuvan tiedon ja tietämyksen johtamisesta?

Liikkeenjohdolliset opit matkustavat maailmalla. Opit syntyvät, leviävät ja muuntuvat levitessään. Opit leviävät ajasta ja paikasta toiseen yhä nopeammin ja tehokkaammin. Liikkeenjohdon konsultit ovat keskeinen osa oppien leviämisen maailmanlaajuista “järjestelmää” (Engwall 1999). Tässä "järjestelmässä” osa opeista kiihtyy nopeasti muodeiksi. Joskus on kyse sattumasta, mutta useimmiten määrätietoisesta työstä. Oppeja tuotetaan, tuotteistetaan ja markkinoidaan. Markkinatalouden mekanismit toimivat kuten millä tahansa muulla liiketoiminnan alueella.

Näyttää siltä, että päätöksentekijöiden käyttäytyminen muuttuu ajasta ja paikasta riippumatta yhä samankaltaisemmaksi. Jotkut sanovat, että tämä ajatusmallien ja tapojen homogenisoituminen ja standardisoituminen on osa väistämätöntä globalisaatiota (ks. esim. Friedman 2000).

Toiset ovat sitä mieltä, että kyse ei ole niinkään globalisoitumisesta, vaan ennen kaikkea amerikkalaistamisesta, joka kuitenkin törmää itsepintaisiin paikallisiin malleihin ja toimintatapoihin (ks. esim. Guillén 1994; Djelic 1998). Tämän näkemyksen mukaan ajatusten ja tapojen standardisointi ei ole väistämätöntä, vaan tiettyjen toimijoiden tietoinen pyrkimys myydä ja virallistaa oma "totuutensa" yhä uusissa ympäristöissä ja tapahtumayhteyksissä. "Totuudet" kohtaavat epäilyksiä ja vastustusta. Ne sopeutuvat ja muuntuvat ${ }^{3}$. Paikallisten käytäntöjen monimuotoisuus säilyy.

Niin tai näin, liikkeenjohdollisten oppien leviämisellä on omat logiikkansa. Yllä esitettyihin kysymyksiin voidaan hakea vastauksia muodin käsitteen avulla.

\section{Liikkeenjohdolliset opit muoteina: anglo-amerikkalainen perinne}

Frederick Winslow Taylorin tieteelliseksi liikkeenjohdoksi ristimä tekniikkapaketti oli modernin maailman ensimmäinen liikkeenjohdollinen muoti. Taylorin opit saivat vuosien 1910 ja 1912 välillä Yhdysvalloissa nopeasti aikaan "tehokkuusmanian”. Taylorin opin kulmakivet olivat horjumaton usko tieteelliseen järkeilyyn, ihmisen rationaalisuuteen ja ajatukseen siitä, että ihminen tekee työtä taloudellisten päämäärien vuoksi. Taylorin opivat myivät yhtäkkiä kuin häkä.

F.W. Taylorin menestys ei ollut sattumaa. Hänen tekniikkapakettinsa oli vastaveto 1800-luvun lopun vallitsevalle opille, joka korosti työnantajien vastuuta työntekijöistään. Erityisesti insinööritaustaiset amerikkalaiset liikkeenjohtajat etsivät kuitenkin jo uusia koordinoinnin ja valvonnan välineitä. Taylorin pääteokseksi jäi bestseller The Principles of Scientific Management, joka julkaistiin ensimmäisen kerran 1911. Taylorin opit 
puolestaan kyseenalaistettiin 1920-luvulta lähtien uusien liikkeenjohdollisten tuulien kautta. Elton Mayon mestaroiman "ihmissuhteiden koulukunnan" opit palauttivat silloin monien yritysjohtajien mielenkiinnon takaisin työntekijöiden hyvinvointiin tehostustoimien kyllästämissä organisaatioissa.

Stephen R. Barley ja Gideon Kunda (1992) esittävät hahmotuksen anglo-amerikkalaisen liikkeenjohdollisen ajattelun aaltomaisesta luonteesta. Tälle ajattelulle on luonteenomaista vuorottelu rationaalista ja normatiivista kontrollia korostavien painotusten välillä.

Aaltomaisuuden voidaan nähdä pohjautuvan siihen, että anglo-amerikkalainen tapa hahmottaa maailmaa rakentuu vastakkaisten filosofioiden taistelulle. Selvimmin tämä näkyy politiikassa. Toisin kuin esimerkiksi Suomessa, anglo-amerikkalainen poliittinen järjestelmä perustuu kahden puolueen kilpailuun (hallitus)vallasta. Eniten ääniä kerännyt saa "kaiken".

Heilahtelut ovat myös osa anglo-amerikkalaista liikkeenjohdollista ajattelua. Välillä on vallalla käsitys, joka korostaa ihmisen yhteisöllisyyttä ja luovuutta. Vastaus on normatiivinen kontrolli. Johtajan tehtävä on luoda mahdollisuuksia ja kirvoittaa luovuutta. Monimuotoiset työtehtävät toimivissa työyhteisöissä muokkaavat lojaaleja työntekijöitä, jotka ottavat vastuun oman yhteisönsä menestymisestä. (Barley ja Kunda 1992)

Välillä on vallalla käsitys ihmisestä laskelmoivana yksilönä; järkiperäisenä tarpeiden tyydyttäjänä, jota motivoi työelämässä ensisijaisesti taloudelliset kannusteet. Vastaus on rationaalinen kontrolli. Johtajan tehtävä on tehostaa; pilkkoa työ osiin ja luoda palkitsemisjärjestelmiä, joiden avulla jokaista osaa varten löytyy tekijä. (Barley ja Kunda 1992)

Barleyn ja Kundan (1992) mukaan normatiivista kontrollia on korostettu erityisesti silloin, kun taloudellinen kasvu on yhteiskunnassa vakiintunut. Rationaalinen kontrolli on saanut tilaa erityisesti laskukausien aikana. Liikkeenjohdolliset opit eivät kuitenkaan pelkästään seuraa talou- den suhdanteita ja yritysten taloudellista tulosta. Tiettyjen oppien suosio juontaa juurensa siitä, että johtajatkin ovat vain ihmisiä.

\section{Liikkeenjohdolliset opit muoteina: mielikuva järjestä ja edistyksestä}

Välitön syy-yhteys tietyn liikkeenjohdollisen opin ja sitä toteuttavan yrityksen tai julkisen sektorin organisaation taloudellisen menestyksen välillä on useimmiten mahdoton osoittaa. Opeissa ja muodeissa on varsinaisen sisällön lisäksi siis myös myyttisiä elementtejä. Mutta miksi liikkeenjohtajien - terveen järjen ja kiireisen arjen kyllästämien ammattilaisten - pitäisi "uskoa" myyttejä?

Muodit ja myytit luovat järjestystä kaoottiseen maailmaan. Eric Abrahamsonin (1996) mukaan modernien, muodikkaiden liikkeenjohdollisten oppien tulee näyttäytyä järkiperäisinä ja edistyksellisinä. Opit myydään sekä parantavien vaikutusten että uutuuden avulla. Tämä johtuu ennen kaikkea siitä, että yritysjohtajien tulee näyttää sekä järkiperäisiltä että edistyksellisiltä oman uskottavuutensa säilyttämiseksi.

Rationaalisen päätöksenteon mallitus on kyseenalaistettu organisaatio- ja liikkeenjohtotutkimuksessa jo pitkään (March ja Simon 1958; Cyert ja March 1963). Yhtäältä voidaan todeta, että liikkeenjohtajien päivittäisessä työssä ratkaisut etsivät ongelmia, pikemminkin kuin päinvastoin (March 1981). Toisaalta esimerkiksi matkiminen on oleellinen osa liikkeenjohdollisten oppien leviämistä (DiMaggio ja Powell 1983).

Uskottavuutta etsivät liikkeenjohtajat löytävät konsulteista avuliaan vastinparin. Liikkeenjohdon konsultit eivät ainoastaan siirrä ja välitä tietoa. He myös legitimoivat - "virallistavat" - yritysjohtajien järkiperäisyyttä. Ja kun yksi johtaja näyttää rationaaliselta, toinen ei voi olla pekkaa pahempi. On tärkeä muistaa, että myös liikkeenjohdon konsultointi on liiketoimintaa. Myös konsultointiyritysten itsensä pitää samanaikaisesti pyrkiä olemaan sekä "ajan hengessä” että erilaisia kuin kilpailijansa. 
Perinteinen tapa kritisoida jonkin tuotteen tai palvelun myyjää on todeta, että kaupan on "vanha viini uudessa pullossa”. Nimike muuttuu, mutta sisältö säilyy samana. Eräs mielenkiintoinen piirre liikkeenjohdollisten oppien ja muotien kentällä on kuitenkin myös se, että saman nimikkeen alla saatetaan myydä ja ostaa erisisältöistä tuotetta. Otsikot erkanevat joustavasti sisällöistään, kun konsultit maastouttavat oppeja yksittäisiin asiakasorganisaatioihinsa (Benders et al 1998; Armbrüster ja Kipping 1999): asiakas saa muokatun tuotteen tilaamansa otsikon alla.

Voidaan siis esittää, että liikkeenjohtajien uskottavuus kiinnittyy ennen kaikkea otsikoiden leviämiseen. Lisäksi yksittäiset päätöksentekijät tekevät valintojaan osana maailmanlaajuista "järjestelmäă”, jossa he altistuvat juuri tietynlaisille vaikutteille. Ajan henki ohjailee kunakin hetkenä rationaaliseksi tulkittujen vaihtoehtojen valikoimaa. Välillä on muodissa lyhyt helma, välillä pitkä helma.

\section{Liikkeenjohdolliset opit muoteina: lyhyt helma, pitkä helma}

Alfred Kieser (1997) vertaa liikkeenjohdollisten oppien tulemista ja menemistä naisten vaatemuodin vaihteluun. Hän korostaa erityisesti retoriikan merkitystä muotien levittämisessä ja leviämisessä. Muodit luodaan puhumalla.

Kieser (1997) esittelee kolme perusmallia siitä, miten liikkeenjohdollinen muotiteollisuus toimii. Muotien vaihtelua voidaan hänen mukaansa ymmärtää esimerkiksi “valumisteorian” kautta. Naisten vaatemuodissa varakkaat edelläkävijät houkuttelevat valinnoilleen jäljittelijöitä. Alemmat sosiaaliryhmät jäljittelevät ylempien tyyliä. Jäljittelijät pakottavat edelläkävijät näin uusiin muutoksiin, jotta ero edelläkävijöiden ja jäljittelijöiden välillä palautuisi ennalleen.

Liikkeenjohdollisten oppien maailmassa valumisteorian voi hahmottaa esimerkiksi siten, että konsultit työstävät luotettujen avainasiakkaidensa kanssa hankkeita, joissa tuotettua tietoa ${ }^{4}$ mo- nistetaan konsulttien myöhemmin muualla toteuttamissa hankkeissa. Tieto valuu edelläkävijöiltä jäljittelijöille. Uusi oppi muuntuu vähitellen massatuotteeksi. Edelläkävijäasiakkailla ja konsulteilla on sen jälkeen intressi palauttaa vanha tasapaino ennalleen uusien hankkeiden ja uuden tiedon kautta.

Erityisesti julkisten organisaatioiden päätöksentekijöiden on syytä olla tarkkana. Julkisella sektorilla on suuri riski joutua vanhojen muotien kaatopaikaksi. Konsulteille on edullista monistaa tiettyä oppia niin pitkään kuin mahdollista, ovathan esimerkiksi tuotekehittelyn ja markkinoinnin aiheuttamat kustannukset jo kertaalleen upotettuja.

Muoti voidaan Kieserin (1997) mukaan käsittää myös kapitalistisen talouden luonnollisena tulemana. Kyse on kilpailuedun luomisesta erojen avulla. Kärjistetysti voidaan sanoa, että fiktiivisiä eroja luodaan sinne, missä todellisia ei ole. Muotituotteiden luojat ja muotiviestien välittäjät hyötyvät erojen tekemisestä eli muotien vaihtelusta. Kieser (1997) kutsuu tätä marionettiteoriaksi. Liikkeenjohdollisten oppien kuluttajista tulee tuottajien marionetteja.

Kieserin (1997) mukaan erityisesti erojen tekemiseen keskittyvä marionettiteoria auttaa ymmärtämään liikkeenjohdollisten oppien ja muotien nykykenttää. Tärkein pelimerkki tällä kentällä on retorinen kyvykkyys; kyky suostutella. Kyse on siis ennen kaikkea markkinoinnista ja myyntityöstä. Osa suostuttelua on se, että oppiin lyödään väistämättömyyden leima.

Liikkeenjohdon konsulttien puhe perustuu usein väitteisiin väistämättömyydestä. "Muutos on väistämätöntä, mutta harva hyödyntää...”. Perusteet muutokselle rakennetaan ulkokohtaiseksi: "toimintaympäristöt muuttuvat, joten myös yritysten pitää muuttua". Muuttaminen tarjoillaan asiakkaille selviytymisen edellytyksenä. Samanaikaisesti annetaan ymmärtää, että muuttamiseen ja muuttumiseen tarvitaan "ulkopuolisia, puolueettomia" näkökulmia - sekä juuri tietty, toimintaympäristöön ja aikaan sopiva liikkeenjohdollinen oppi ja/tai työkalu. 
Muoti voidaan hahmottaa myös kollektiivisen sosiaalisen valinnan avulla (Kieser 1997). Muoti tuo järjestystä monimutkaiseen, epävarmaan ja kaoottiseen todellisuuteen. Muoti rajoittaa mahdollisten, sopivien ratkaisujen kirjoa. Toimija yritysjohtaja tai päätöksentekijä julkisen sektorin organisaatiossa - luo siis itselleen hetkellisen tasapainotilan olemalla muodikas. Samalla muoti luo linkin menneisyyden, nykyhetken ja lähitulevaisuuden välillä. Muotien ketjussa on turvallista olla mukana.

Tämä vastaa osaltaan siihen, miksi monet yritysjohtajat ja julkisen sektorin päätöksentekijät ovat kroonisia ulkopuolisten neuvonantajien käyttäjiä. Kuten mistä tahansa nautintoaineesta, konsultoinnista voi tulla riippuvaiseksi ${ }^{5}$.

Organisaatiot ovat koko ajan matkalla jonnekin. Ne elävät ikuista siirtymää. Konsultit auttavat siirtymän eri vaiheiden ja virstanpylväiden sekä siirtymää tukevien uskomusten luomisessa. Siirtymävaiheiden uskomukset luodaan usein jonkin tietyn opin avulla. Uskomukset paremmasta huomisesta saavat aikaan toimintaa. Kollektiiviset uskomukset uusien oppien ylivoimaisuudesta toimivat välineenä halutun "muutoksen” käynnistämiseksi. Odotukset muuttuvat itseään toteuttaviksi ennusteiksi. Uskomuksilla on siis todellista välinearvoa. (Ks. esim. Abrahamson 1996; Ainamo 1999)

Yritysjohtajien ja konsulttien välinen suhde on näin ollen symbioottinen. Kummallakin on tapana kehua toisiaan. Kumpikaan ei halua konsultointihankkeiden ylle epäonnistumisen leimaa. (Ks. esim. Abrahamson 1996; Ainamo 1999; vrt. Sturdy 1997)

Konsulttien muotituotteiden kuluttajat eivät siis yleensä ole tahdottomia marionetteja. Opit ja muodit kuitenkin muuttavat ihmisten elämää. Puheilla on taipumus ennen pitkää materialisoitua toiminnaksi, vaikka tämä toiminta ei välttämättä ole alkuperäisen otsikon mukaista. Kysymys siitä, onko jokin asia muuttunut vai ei, saa eri vastauksia tarkastelun näkökulmasta ja aikajänteestä riippuen.
On lisäksi syytä korostaa, että yksittäisten liikkeenjohdollisten oppien alkulähde voidaan yleensä paikantaa organisaatioiden päivittäisessä elämässä esiin nouseviin ongelmiin ja ratkaisuihin (ks. esim. Furusten 1995). Opin kiertokulku muodiksi alkaa yleensä yksittäisten yritysten ja toimijoiden tyytymättömyydestä, pettymyksestä ja/tai oivalluksesta. Se alkaa tilanteista, joissa olemassa oleva ei riitä. Jossakin kokeillaan uusia ratkaisuja. Joku (esimerkiksi konsultti) "löytää" parhaat ratkaisut, käsitteellistää ne ja paketoi ne myyviksi tuotteiksi. Kiertokulku jatkuu.

Liikkeenjohdollisten oppien otsikot "matkustavat" maailmalla yhä nopeammin. Sisällöt seuraavat perässä ja sopeutuvat erilaisiin tilanteisiin ja tapahtumayhteyksiin. Kenties yllä esitetty ajatus siitä, että käytäntöjen monimuotoisuus säilyy globalisoituvassa maailmassa pitää paikkansa ainakin lyhyellä aikajänteellä. Se, mikä on lyhyt aikajänne, onkin sitten vaikeampi määritellä.

Seuraavassa esitellään lyhyesti kolme liikkeenjohdollista oppia, joiden leviäminen sai tietyissä toimintaympäristöissä ja tiettynä historiallisena hetkenä muodin piirteitä: kulttuuri, prosessit ja tiedon johtaminen. Kukin opeista ilmensi (tai ilmentää) aikaansa, mutta ei tietenkään ollut (tai ole) ajassaan ainoa. Esitetyn kolmen opin välinen keskinäinen syy-seuraus -suhde ei myöskään ole yksioikoinen. Opit eivät ole yksiselitteisesti seuranneet toisiaan yksittäisissä organisaatioissa. Jokaisen nyt esitetyn opin voidaan myös sanoa elävän edelleen - kukin tavallaan, muuntuneena yhä uusiin tapahtumayhteyksiin.

\section{Ajatus, jonka aika on tullut}

Victor Hugon mukaan "hyökkäävää armeijaa voi vastustaa, muttei ajatusta, jonka aika on tullut". Tämän lentävän lauseen ${ }^{6}$ voi tulkita esimerkiksi siten, että vyöryvä armeija on näkyvä ja konkreettinen, mutta ajatus on näkymätön ja taipuisa. Sitä, mitä ei näe, on vaikea kyseenalaistaa ja vastustaa.

\section{Kultturi}

Kulttuurin käsite levisi länsimaisissa yrityksissä 
kulovalkean tavoin 1980-luvun alkupuolella. Kuten liikkeenjohdolliset muodit yleensä, myös tämä villitys lähti liikkeelle Yhdysvalloista. Kulttuuri on klassinen esimerkki "gurujen" merkityksestä liikkeenjohdollisten muotien levittämisessä. Se, miten kulttuurin käsite levisi, liittyy myös olennaisesti suunnanmuutokseen monien konsultointiyritysten suhteessa julkisuuteen ${ }^{7}$.

Tom Petersin ja Robert Watermanin kirja In Search of Excellence (1982) iski suoraan amerikkalaisen johtajan tajuntaan. Peters ja Waterman kertoivat viestinsä juuri silloin, kun jenkkijohtajat olivat kyllästyneet kuulemaan tarinoita japanilaisten johtamis- ja organisaatiomallien erinomaisuudesta. Petersilla ja Watermanilla oli ennen kaikkea taito ajoittaa viesti ja ilmentää aikansa ilmapiiriä. He korostivat kirjassaan "erinomaisten" yhdysvaltalaisten yritysten reseptejä.

Peters ja Waterman toimivat McKinsey \& Co:n konsultteina. He kirjoittivat asiakasyrityksissä kohtaamistaan menestystarinoista sekä menestyksen salaisuuksista, jotka eivät olleet suoraan johdettavissa perinteisestä strategia-rakenne -ajattelusta. Peters ja Waterman siirsivät liikkeenjohdollisen ajattelun painopistettä uudestaan kohti "pehmeämpiä" tekijöitä. Heidän viestinsä koostui kahdeksasta erinomaisen yrityksen kulttuurisesta piirteestä. Kirja sai liikkeenjohtamisen kuulostamaan yksinkertaiselta ja helpolta. Petersilla ja Watermanilla oli taito saada viestinsa perille vetoamalla käytännölliseltä kuulostaviin yleispäteviin neuvoihin. ${ }^{8}$

Kahdesta kirjoittajasta shown varasti loppujen lopuksi Tom Peters. Hän oli - ja on - ainutlaatuinen myyntimies. Peters jätti McKinseyn ja ryhtyi kokopäivätoimiseksi guruksi. Tom Petersia on kutsuttu "gurujen kantaisäksi", , joka loi peruskaavan seuraajilleen.

Ensiksi tuodaan markkinoille kirja. Laajaa levitystä varten rakennetuilla kirjallisilla tuotteilla, bestsellereillä on liikkeenjohdollisten oppien ja muotien kentässä keskeinen paikka. Bestsellerit ovat muotien soihdunkantajia. Kieser (1997) hahmottelee kymmenen tekijää, joiden varaan myyvä bestseller usein rakennetaan:
1 Yhden tekijän korostaminen. Liikkeenjohdollisen bestsellerin tulee pystyä nostamaan esille yksi aiemmin aliarvioitu tai unohdettu tekijä, jonka uusi ja parempi hyväksikäyttö saattaa johtaa menestykseen. Esimerkkejä ovat kulttuuri, laatu, yrittäjyys, prosessit, verkostot ja tieto. Bestseller korostaa yhden tekijän radikaalia ja vallankumouksellista eroavaisuutta aiemmin korostetuista. Sovellettavien periaatteiden ja toimenpiteiden lista johdetaan tästä yhdestä tekijästä.

2 Väistämättömyys. Bestseller tuo korostetusti esille sen, että uusien periaatteiden ja toimenpiteiden toteuttaminen on paitsi välttämätöntä, myös väistämätöntä. Toteuttamatta jättäminen johtaa tuhoisiin seurauksiin. Bestseller siis sisältää yleensä uhkakuvan. On pakko ainakin yrittää.

3

Yhteys yleviin arvoihin. Bestsellerin tarjoamalla viestillä tulee olla helposti ymmärrettävä yhteys joihinkin perustavaa laatua oleviin, myönteisiin tulemiin. Näitä tulemia kutsutaan arvoiksi. Esimerkkejä ovat tuloksellisuus, kilpailukyky, asiakastyytyväisyys, yhteistyö, joustavuus, dynaamisuus ja luovuus.

4 Loistavat esimerkit. Hyvä bestseller ei osoittele lukijaansa, vaan vetoaa loistaviin esimerkkeihin edelläkävijöistä. Bestseller puhuttelee lukijaansa esimerkein, jotka sopivat lukijan ensisijaisesti yritysjohtajan - omaan kokemusmaailmaan. On myös tärkeä korostaa uusien periaatteiden soveltuvuutta ja sovellettavuutta lukijan toimintaympäristöön. Tarjottujen periaatteiden ja toimenpiteiden tulee siis nousta suoraan käytännön esimerkeistä, eikä esimerkiksi tutkijan kammiosta. Menestyvät edelläkävijät ikään kuin virallistavat tarjotun totuuden.

5

Seuraaminen ei ole häpeä. Lukijan ei tule saada huonoa omaatuntoa siitä, että ei ole keksinyt uusia periaatteita itse. Hyvä bestseller maalaa kuvan maailmasta, joka muuttuu jatkuvasti ja yhä kiihtyvämmällä tahdilla. Näin ollen myös parhaat liikkeenjohdolliset ratkaisut muuttuvat jatkuvasti. Lukijan pitää saada tarpeeksi kiinnikkeitä omaan todellisuuteensa, mutta hänen pitää myös pystyä tulkitsemaan saavansa bestselleristä jon- 
kin "uuden" virikkeen.

6 Yksinkertaistukset ja epämääräisyydet. Hyvät bestsellerit rakentuvat sopivasta yhdistelmästä yksinkertaistuksia ja epämääräisyyksiä. Perusviestin pitää tietenkin olla mahdollisimman yksinkertaisessa muodossa. Uuden tekijän erinomaisuus pitää muotoilla selkeästi; esimerkiksi sisäisen yrittäjyyden erinomaisuus verrattuna vanhanaikaiseen byrokratiaan. Ympärillä olevan tekstin pitää kuitenkin olla sopivan epämääräistä: lukuisista esimerkeistä huolimatta sisäiseen yrittäjyyteen perustuva organisaatiomalli jätetään lopullisesti määrittelemättä. Yrityskohtainen räätälöinti on bestsellerin (ja konsulttien) takaportti ja elinehto.

\section{$7^{\mathrm{s}}$}

Epäonnistumisen riski on olemassa. Hyvä bestseller jättää itselleen aina myös toisenlaisen takaportin. Kirjoittaja tekee lukijalle selväksi sen, että suurin osa kunnianhimoisista hankkeista uusien periaatteiden ja toimenpiteiden toteuttamiseksi epäonnistuu. Muuttuminen tarjoaa siis valtavan haasteen. Ne harvat, jotka onnistuvat, onnistuvat loistavasti. Bestsellerin juoni siis yleensä rakennetaan "voittaja saa kaiken" -ajatusta myötäillen. Eli: eihän kukaan olisi voittaja, jos kaikki onnistuisivat.

Q Vihjaukset teoriapohjaan. Hyvä bestseller antaa viestinsä nousta käytännön esimerkeistä. Vihjaukset laajempaan, systemaattiseen empiiriseen tutkimukseen kuitenkin auttavat viestin perille menoa. Tieteellisen tutkimustyön tylsästä taustasta - tutkimusmetodeista, luotettavuudesta jne. - kerrotaan mahdollisimman vähän. Muutamat vihjaukset esimerkiksi huippuyliopistoihin ja/tai huippututkijoihin riittävät. Mielenkiintoista on, että ensimmäinen, artikkelimuotoinen aihio monista bestsellereistä (ja liikkeenjohdoillisista opeista) on julkaistu jonkin arvostetun "bisneskoulun" puoliakateemisessa julkaisusarjassa. Keskeisin esimerkki tällaisesta julkaisukanavasta on Harvard Business Review.

9 Helppolukuisuus. Hyvä liikkeenjohdollinen bestseller on aina helppolukuinen. Se sisältää lyhyitä lauseita. Kielen ja kielikuvien pitää olla eläviä. Akateemista vaikeaselkoisuutta tulee välttää. Tarinat menestyjien suulla kerrottuna edesauttavat viestin perillemenoa.

10 Ajoitus on kaikki. Kaikki edellä mainitut hyvän bestsellerin piirteet ovat turhia, jos markkinoiden valtaamisen ajoitus ei ole tarkkaan harkittu (olettaen, että bestsellerin kirjoittajalla ei käy pelkästään uskomaton onni).

Kun huolellisesti markkinoitu bestseller alkaa ottaa tuulta siipiensä alle, guru jalkautuu luento- ja seminaarikiertueelle. Valikoidut yleisöt kuulevat uudet opit tuoreeltaan. Osa kuulijoista välittää omiin organisaatioihinsa tarpeen soveltaa juuri näitä oppeja. Konsultointihankkeet käynnistyvät yhä uusissa edelläkävijäyrityksissä.

Organisaatio- ja yrityskulttuurimuoti saavutti huippunsa 1980-luvun loppupuolella. Tämän jälkeen kulttuuri on vähitellen saanut väistyä uusien muotien tieltä. (Ks. esim. Kieser 1997)

Petersin ja Watermanin vuoden 1982 "erinomaisista” yrityksistä monet olivat vakavissa taloudellisissa vaikeuksissa jo viisi vuotta myöhemmin. Tästä puolestaan johdettiin opetus, jonka mukaan menestys pitää sisällään paikoilleen juuttumisen ja epäonnistumisen siemenen. Muutoksen ja muuttumisen teemat ovatkin olleet 1990luvun liikkeenjohdollisten oppien ja muotien ydin.

Tom Petersin guru-ura jatkuu yhä. Peters on urallaan rakentanut oppeja ja muoteja useiden eri teemojen avulla. Niistä viimeisimmät ovat monilta osin ensimmäisten antiteesejä (Micklethwait ja Woolridge 1997). Keskeinen osa guruutta on haistaa "ensimmäisenä" ajan henki. Yksittäiset gurut ovat kuitenkin ennen kaikkea julistajia ja viihdyttäjiä ${ }^{10}$. Kieserin (1997) ajatus retoriikan merkityksestä liikkeenjohdollisten oppien leviämisessä tulee tässä erityisen korostuneesti esille.

\section{Prosessit}

Liikkeenjohdollinen prosessiajattelu levisi maailmalle 1990-luvun alkuvuosista lähtien. Tämä on klassinen esimerkki siitä, miten tietty oppi tuotteistetaan, nimetään ja vyörytetään markki- 
noille. Prosessiajattelu on myös hyvä esimerkki siitä, miten tietty oppi ja muoti luo alustan seuraavalle opille ja muodille.

Tämän opin alkuperäinen nimi on Business Process Re-engineering. BPR:n leviämisen alkupamaus oli Michael Hammerin kirjoittama artikkeli Harvard Business Review:ssa (1990). Varsinaista läpimurtoa joudutti Hammerin ja James Champyn bestseller Reengineering the Corporation: A Manifestofor Business Revolution (1993).

Myös BPR:n kohdalla ajoitus oli olennainen osa menestystä. Eräs pohjimmainen syy BPR:n onnistuneelle maailmanvalloitukselle oli yritysjohtajien turhautuminen. Päätöksentekijät ympäri maailmaa olivat pettyneitä kahteen asiaan, joihin he olivat juuri aikaisemmin sitoutuneet ja investoineet: teknologiaan ja laatuun (Micklethwait ja Woolridge 1997). Kenties he olivat pettyneitä myös "pehmeisiin” kilpailutekijöihin, joita esimerkiksi kulttuurimuoti korosti.

Vaikka teknologiaan ja laatuun oli jo 1980-luvulla sijoitettu paljon rahaa, useimmat yritykset jauhoivat liiketoimintaansa entiseen malliin. Teknologia ja laadun kehittäminen oli ladattu vanhan päälle, usein vielä erillisinä palasina. Yrityksen konetta ei ollut "piirretty uudelleen". BPR tarjosi tähän lääkkeen. Vanha kone hajoitettiin komponentteihinsa. Uusi, tehokkaampi kone rakennettiin samoista komponenteista liiketoimintaprosessien ympärille. Prosessit viritettiin teknologian avulla tehokkaiksi. Turhaksi leimattu ihmistyö - eli ylimääräiset kustannukset karsittiin pois. Kovat arvot tekivät näyttävän paluun. (Benders et al 1998; Heusinkveld et al 2000)

Liiketoimintaprosessien uudistaminen tietotekniikan avulla tarjoaa muodikkaan esimerkin myös lamanjälkeisestä Suomesta. Suomi oli 1990-luvun alkuvuosien laman jälkeen erityisen hedelmällinen maaperä prosessien uudistamiselle. Tehokkuus, järkeistäminen ja alasajo kuulostivat päätöksentekijöiden korvissa aikaan sopivilta "väistämättömiltä” ratkaisuilta. Erityisesti vuosien 1994 ja 1995 aikana Suomen kirjamarkkinoille ilmestyi useita oppaita, jotka korostivat yritysten ydinprosessien tehostamista ja uudistamista (ks. esim. Hannus 1994; Laine ja Tiirikainen 1994; Nyman ja Silén, 1995).

Keijo Räsänen (1998) pitää BPR-opin nopean kasvun ja leviämisen yhtenä syynä sitä, että se tarjosi liikkeenjohtajille oikeutuksen rajuihin ja väkivaltaisiin toimiin. Myös amerikkalaisten BPRgurujen - Michael Hammer etunenässä - kerrotaan lopulta päivitelleen sitä, että heidän kauppaamastaan opista oli monissa organisaatioissa tullut vain julkisivu toimintojen karsimiselle ja irtisanomisille. BPR sai monissa yrityksissä ja julkisen sektorin organisaatioissa aikaan "saneerausfestivaalit”. (Ks. O’Shea ja Madigan 1997; Micklethwait ja Woolridge 1997)

Liiketoimintaprosessien uudistamisen retoriikkaan kuului alusta asti olennaisena osana se, että suurin osa hankkeista epäonnistuu. BPR-julistuksen mukaan vain oikeaoppiset toteuttajat onnistuvat - eikä heistäkään kaikki (Hammer ja Champy 1993). Tämä retoriikka pohjustaa muun muassa sen, että konsultoinnin tarve BPR:aa soveltaneissa organisaatioissa jatkuu.

Alasajavan uudellenorganisoinnin hyödyt jäivät yleensä varsin lyhytaikaisiksi. Tietotekniikka oli edelleen jäänyt irralliseksi elementiksi BPR:iä soveltaneiden organisaatioiden toiminnassa. BPR:n suomat mahdollisuudet eivät keskeisesti johdatelleet ylimmän johdon päätöksentekoa. Luurangoiksi saneeratut organisaatiot eivät näin olleet välittömästi valmiita hyödyntämään kasvavien markkinoiden ja informaatioteknologian kehittymisen suomia mahdollisuuksia.

\section{Tiedon johtaminen}

Informaatioteknologiasta rakentui 1990-luvun jälkimmäisellä puoliskolla yhä selvemmin maailmanlaajuisen "muutoksen" moottori. Räjähdysmäisesti kehittyvän teknologian suomat, rajattomiksi kutsutut mahdollisuudet informaation siirtämisessä ja muokkaamisessa loivat yritysjohtajille tarpeen hallita tiedon luomista ja käyttämistä omissa organisaatioissaan.

Käsite "knowledge management" (KM) pitää si- 
sällään ajatuksen tiedon johtamisesta liiketoimintaprosessina. Miklos Sarvaryn (1999) mukaan tämä prosessi koostuu tiedon hankkimisesta, muokkaamisesta ja jakamisesta. KM on hänen mukaansa "teknologia, joka muuttaa informaatiota tiedoksi" "11 . KM:n retoriikkaan kuuluu korostaa sitä, että kyse on uudesta tietoisuudesta hahmottaa tiedon johtaminen prosessina.

Suomessa tiedon johtamisen ovat pukeneet myyvään muotoon esimerkiksi Pirjo Ståhle ja Mauri Grönroos (1999) Ekonomia -sarjan kirjassa Knowledge Management: tietopääomayrityksen kilpailutekijänä. "Dynaamisessa" ympäristössä tietopääoma asettuu muiden tuotannontekijöiden rinnalle johtajien johdettavaksi. Tiedon johtamiseen elimellisesti liittyviä käsitteitä ovat esimerkiksi organisaation ja yksilöiden osaaminen, valmiudet ja oppiminen. Avainsanoja ovat myös muun muassa innovointi, intuitiivisuus, spontaanius ja kaoottisuus (Ståhle ja Grönroos 1999).

Mielenkiintoista tiedon johtamisessa on se, että konsultointitoimistot kauppaavat tällä kertaa toimintatapoja, joiden soveltamisessa ne ovat itse olleet edelläkävijöitä ${ }^{12}$. Suuret kansainväliset konsultointiyritykset kokoavat asiakastoimeksiantojensa "parhaat käytännöt" (ongelmat, toimintatavat ja ratkaisut) laajoiksi tietopankeiksi. Konsultointiyritykset siis työstävät järjestelmällisesti asiakastietoa. Tieto jäsennellään ja sovelletaan aikanaan muihin asiakastoimeksiantoihin.

Esimerkiksi Andersen Consulting Oy: ${ }^{13}$ toimitusjohtaja Markku Silén puhuu “järjestelmällisestä tiedonhallinnasta, joka perustuu maailmanlaajuiseen tietoarkkitehtuuriin". Andersen Knowledge Xchange -järjestelmässä on noin 3500 tietokantaa ja 1,5 miljoonaa sivua tietoa. Periaatteena on, että Andersen Consultingin jokaisessa asiakastoimeksiannossa on nimetty konsultti, joka varsinaisen tehtävänsä ohella toimii "knowledge championina”, jonka vastuulla on toimeksiannon aikana kertyvän tiedon analysoiminen ja tallentaminen AC:n maailmanlaajuiseen tietojärjestelmään muiden hyödynnettäväksi. Kyse on siis pohjimmiltaan suurtuotannon eduista. (Ks. esim. Laatuviesti 2/2000)
Konsultointitoimistoilla on kuitenkin sama perusongelma kuin asiakkaillaan: miten saada ihmiset jakamaan tietoa? Tietopääoman johtaminen limittäin perinteisten, yksilösuorituksiin perustuvien palkitsemis- ja urajärjestelmien kanssa on osoittautunut vaikeaksi. (Ks. esim. Bartlett 1997). Yksilöllä on taipumus pitää tiedonjyväsiä valttikortteina hihassa, koska yksin hallitut tiedonjyväset tekevät juuri hänestä arvokkaan ja tärkeän. Tieto on vaihdannan väline.

Nykyretoriikassa jaottelu datan, informaation ja tiedon välillä ei enää tunnu riittävän. Suomenkielessä on lopulta pitänyt tehdä ero tiedon ja tietämyksen välillä. Informaatioteknologiaa korostavan maailman todellisuustaskuihin jạä tarve inhimilliselle kanssakäymiselle. Esimerkiksi japanilaisen professori Ikujiro Nonakan tunnetuksi tekemä käsite "hiljainen tieto" on noussut myyttiseen asemaan osaamista ja oppimista ihannoivassa muutosmaailmassa (ks. esim. Nonaka ja Takeuchi 1995). Informaatioteknologia on luonut jälleen markkinaraon guruille ja konsulteille, jotka korostavat myös liiketoiminnan inhimillisiä elementteja.

\section{Lopuksi: muutoksen kauppiaat ovat aina askeleen edellä}

Yllä on esitetty kirjallisuuskatsauksen avulla näkökulmia siihen, miten ja miksi liikkeenjohdolliset opit muuntuvat muodeiksi. Erityisenä tarkastelun kohteena on konsulttien rooli oppien ja muotien välittäjinä ja kauppiaina.

Vaatemuodin tekijät myyvät ensi kevään tai syksyn mallistoa nyt. Näin tekevät myös liikkeenjohdon konsultit yhdessä niiden asiakkaidensa kanssa, jotka kuuluvat edelläkävijöihin. Muutoksen kauppiaat ovat aina yhden askeleen edellä (vrt. esim. Ainamo ja Tienari 2000).

Liikkeenjohdon konsultit elävät maineellaan. Mainetta tulee pitää jatkuvasti yllä. Jatkuva uudelleenkehittämisen ja tehostamisen tarve on edelleen olennainen osa liikkeenjohdon konsultoinnin markkinoilla menestymistä. Tässä mielessä matka Frederick W. Taylorin tieteellisen liik- 
keenjohdon tekniikoista nykypäivään on varsin lyhyt. Lisäksi vaikka "pehmeät" opit tämän tästä nostavat päätään, Taylorin peräänkuuluttama "kova" järkiperäisyys - tai pikemminkin sitä korostava retoriikka - on yleensä ollut liikkeenjohdollisissa diskursseissa keskeinen elementti (Barley ja Kunda 1992).

Yksittäisen liikkeenjohdollisen opin kiertokulussa oikea ajoitus on kaiken perusta. Kiertokulku alkaa yleensä yritysten ja yksittäisten toimijoiden tyytymättömyydestä ja/tai pettymyksestä olemassa oleviin ratkaisuihin. Jossakin kokeillaan uusia ratkaisuja. Joku (esimerkiksi konsultti) "löytää" parhaat ratkaisut, käsitteellistää ne ja paketoi ne myyviksi tuotteiksi. Ratkaisut julkaistaan bestsellerina ja/tai puoliakateemisina artikkeleina. Tiedotusvälineet valjastetaan uuden opin puolestapuhujiksi. Oppi alkaa levitä ja innostus kasvaa. Oppi muuntuu massamuodiksi. Jonkin ajan kuluttua alkaa nousta uutta tyytymättömyyttä ja uusia pettymyksiä. Muodin uskottavuuspohja alkaa rapautua. Oppien ja muotien kiertokulku jatkuu.

Konsultit sanoutuvat nykyisin kärkkäästi irti yksittäisten oppien ja muotien kauppaamisesta ${ }^{14}$. Konsultit kertovat myyvänsä asiakkaidensa kulloiseenkin tarpeeseen sopivia räätälöityjä kokonaisratkaisuja. Konsulttitoimistoilla on valikoimissaan useita eri elinkaaren vaiheissa olevia liikkeenjohdollisia tuotteita. Suuret konsultointiyritykset ovat siirtyneet yhä selvemmin yksittäisistä opeista suurten ja nopeiden muutosohjelmien kauppaamiseen. Osaltaan tällaiset "integroidut" - tiukasti ylhäältä alas johdetut, "kokonaisvaltaiset" - muutosohjelmat korjaavat aikaisempien oppien aiheuttamia pettymyksiä. (Ks. esim. Tienari 1999)

Ironisesti voisi todeta, että “ismittömyys" on konsultoinnissa nykyisin kuuma muoti. Konsulttien asiakkaiden on kuitenkin edelleen oltava tarkkana liikkeenjohdollisten oppien ja muotien vaikeasti hahmotettavassa maailmassa. Thomas Armbrüster ja Matthias Kipping (1999) erittelevät neljä sudenkuoppaa liikkeenjohdon konsulttien käyttämisessä:
1 Otsikoiden levittäminen. Konsultit ovat yleensä kiinnostuneempia liikkeenjohdollisten oppien nopeasta leviämisestä kuin oppien sisältämän tiedon huolellisesta maastouttamisesta yksittäisiin asiakasyrityksiin. Oppien hioutuminen käytännöiksi on viime kädessä konsultointipalvelun ostajan vastuulla. Keskeistä on kunnioittaa sitä, että muutostilanteet ovat erilaisia (ks. myös esim. Tainio ja Valpola 1996).

2 san Sama paketti, eri tuote. Nopeuttaakseen tiedon leviämistä konsultit vetoavat muotikäsitteisiin, mutta erottelevat nämä käsitteet jostavasti sisällöistään. Jos asiakas vaatii BPR:ää, hän saa tuotteen ja palvelun tämän otsikon alla. Palvelun sisältö voi kuitenkin olla jotain aivan muuta. Räätälöinnin nimissä konsultin vapausaste on korkea. Konsultointipalvelun ostajan (esimerkiksi suuren yrityksen ylimmän johdon, pkyrittäjän tai julkisen sektorin päätöksentekijän) tulee siis pitää huolta siitä, että hänellä on kulloisellekin konsultoinnille konkreettinen tavoite - ja pitää tavoitteestaan kiinni.

3 Konsultit poliittisina avustajina. Konsultit ei$\mathcal{3}$ vät ainoastaan levitä tietoa, vaan myös virallistavat ja auktorisoivat olemassaolevaa tietoa. Palvelun ostajalla on houkutus käyttää konsultteja omien linjanvetojensa ja oivallustensa ${ }^{15}$ virallistajina. Konsulteista tulee yleensä väistämättä poliittisia pelureita yritysten sisälle: jotkut ovat konsulttien visioiden ja toimintatapojen puolesta, jotkut ovat vastaan. Konsultointipalvelun ostajan sitoutuminen konsultointiin ei tarkoita poliittisen puolen valitsemista. Se tarkoittaa vastuuta prosessista.

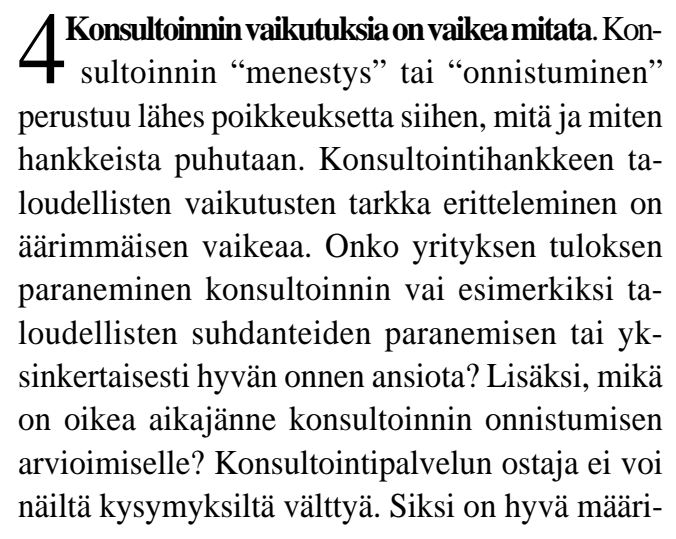

AIKUISKASVATUS 3/2000 
tellä arvioinnin kriteerit ja tarkastuspisteet etukäteen.

Konsultti voi yksinkertaistaa monimutkaista kokonaisuutta tai muotoilla vanhaan kaluttuun asiaan uusia mielenkiintoisia merkityksiä (Czarniawska-Joerges 1990; Ainamo 1999). Kun konsultti puhuu abstraktisti "muutoksesta", asiakkaan pitää muistaa pyytää häntä täsmentämään “muutoksen” käytännön sisältö.

Liikkeenjohdolliset opit ja muodit rakentuvat sosiaalisesti. Opit ja muodit muuttavat ihmisten elämää, koska puheilla on taipumus ennen pitkää materialisoitua toiminnaksi, vaikka tämä toiminta ei välttämättä ole alkuperäisen otsikon mukaista. Otsikot "matkustavat" maailmalla nopeasti, sisällöt seuraavat perässä. Koska opit rakennetaan kussakin tapahtumayhteydessä sosiaalisesti uudelleen, niiden leviäminen ei ole itsessään väistämätön ja vastaansanomaton ilmiö.

\section{Lähteet}

ABRAHAMSON, E. (1996): Management Fashion. Academy of Management Review 21, 254-285.

AINAMO, A. (1999): Konsultti osaa lipaista oikein. Tietoviikko 25.11.1999.

AINAMO, A. \& TIENARI, J. (2000): Consultants and Persistent Divergence in the Finnish Model of Management: The Rise, Fall and Legacy of Local Consultants in a Late-industrializing Country. 16th EGOS Colloquium "Organizational Praxis", Helsingin kauppakorkeakoulu.

ALVESSON, M. ja BERG P-O (1992): Corporate Culture and Organizational Symbolism. New York: Walter de Gruyter.

ARMBRUESTER, T. ja KIPPING, M. (1999): Organizational Change Through the Transfer of Knowledge: Pitfalls in the Use of Management Consultants. SCANCOR Conference on Carriers of Management Knowledge, Stanford University, USA.

BARLEY, S.R. ja KUNDA, G. (1992): Design and Devotion: Surges of Rational and Normative Ideologies of Control in Managerial Discourse. Administrative Science Quarterly 37, 363-399.

BARTLETT, C.A. (1997): McKinsey \& Company: Managing Knowledge and Learning. HBS Case 9-396357 (revised December 15, 1997). Boston: Harvard Business School.

BENDERS, J., VAN DEN BERG, R-J ja VAN BIJSTERVELD, M. (1998): Hitch-hiking on a Hype: Dutch Consultants Engineering Re-engineering. Journal of Organizational Change Management 11, 201-215.

CZARNIAWSKA-JOERGES, B. (1990): Merchants of Meaning. Teoksessa: Turner B.A. (toim.) Organizational Symbolism. Berlin: Walter de Gruyter.

CLARK, T. ja GREATBATCH, D. (2000): Maintaining
Audience Affiliation Through Storytelling: The Case of Management Gurus. Työpaperi esitetty konferenssissa "16th EGOS Colloquium 'Organizational Praxis",, Helsingin kauppakorkeakoulu, 2-4 heinäkuuta.

CYERT, R.M. ja MARCH, J.G. (1963): A Behavioral Theory of the Firm. Englewood Cliffs, NJ: PrenticeHall.

DEAL, T.E. ja KENNEDY, A.A. (1984): Corporate Cultures: The Rites and Rituals of Corporate Life. Reading, MA: Addison-Wesley.

DiMAGGIO, P.J. ja POWELL, W.W. (1983): The Iron Cage Revisited: Institutional Isomorphism and Collective Rationality in Organizational Fields. American Sociological Review 48, 147-160.

DJELIC, M-L (1998): Exporting the American Model. USA: Oxford University Press.

ENGWALL, L. (1999): The Carriers of European Management Ideas. CEMP report No 7. Uppsala University, Department of Business Studies.

FRIEDMAN, T.L. (2000): Globalisaatio - uhka vai unelma. Helsinki: Otava.

FURUSTEN, S. (1995): The Managerial Discourse: A Study of the Creation and Diffusion of Popular Management Knowledge. Uppsala: Uppsala University Press.

GUILLÉN, M. (1994): Models of Management: Work, Authority and Organization in a Comparative Perspective. Chicago: University of Chicago Press.

HAMMER, M. (1990): Reengineering Work: Don't Automate, Obliterate! Harvard Business Review, July-August, 104-112.

HAMMER, M. ja CHAMPY, J. (1993): Reengineering the Corporation: A Manifesto for Business Revolution. London: Brealey.

HANNUS, J. (1994): Prosessijohtaminen: Ydinprosessien uudistaminen ja yrityksen suorituskyky. Espoo: HM\&V Research.

HANSEN, M.T., NOHRIA, N. ja TIERNEY, T. (1999): What's Your Strategy for Managing Knowledge? Harvard Business Review, March-April, 106-116.

HARGADON, A. (1998): Knowledge Brokers: A Field Study of Organizational Learning and Innovation. Academy of Management Best Paper Proceedings '98.

HEUSINKVELD, S., BENDERS, J. ja KOCH, C. (2000): Dispersed Discourse? Defining the Shape of BPR in Denmark and the Netherlands. 16th EGOS Colloquium "Organizational Praxis", Helsingin kauppakorkeakoulu.

HUCZYNSKI, A. (1993): Management Gurus: What Makes Them and How to Become One. London: Routledge.

KIESER, A. (1997): Rhetoric and Myth in Management Fashion. Organization 4, 49-74.

KYRÖ, P. (2000): Liikkeenjohdon konsultointi postmodernin murroksessa. PKT-säätiön julkaisu 2/ 2000.

LAHTI, R.K. ja BEYERLEIN, M.M. (2000): Knowledge Transfer and Management Consulting: A Look at "The Firm". Business Horizons, January-February, 65-74.

LAINE, K. ja TIIRIKAINEN, V. (1994): Ydinketjut uusiksi: Kuinka parannat suorituskykyä soveltamalla re-engineeringiä. Espoo: Suomen Atk-kustannus. LATOUR, B. (1986): The Powers of Association. Teok- 
sessa Law, J. (toim.) Power, Action and Belief. London: Routledge and Kegan Paul.

LILLRANK, P. (1998): Laatuajattelu - laadun filosofia, tekniikka ja johtaminen tietoyhteiskunnassa. Helsinki: Otava.

MARCH, J.G. (1981): Footnotes to Organizational Change. Administrative Science Quarterly 26, 563577.

MARCH, J.G. ja SIMON, H. (1958): Organizations. New York: John Wiley.

MICKLETHWAIT, J. ja WOOLRIDGE, A. (1997): The Witch Doctors: What Management Gurus Are Saying, Why It Matters and How To Make Sense of It. UK: Mandarin Paperbacks.

NONAKA, I. ja TAKEUCHI, H. (1995): The Knowledgecreating Company: How Japanese Companies Create the Dynamics of Innovation. New York: Oxford University Press.

NYMAN, G. ja SILÉN, M. (1995): Muutoshallinta ja Business Reengineering käytännössä. Helsinki: Andersen Consulting.

O'SHEA, J. ja MADIGAN, C. (1997): Dangerous Company: The Consulting Powerhouses and the Businesses They Save and Ruin. New York: Random House.

PETERS, T. ja WATERMAN, R. (1982): In Search of Excellence: Lessons from America's Best Run Companies. New York: Harper \& Row.

RÄSÄNEN, K. (1998): Miten suhtautua BPR-otteeseen korkeakoulun kehittämisessä? Teoksessa Mälkiä, M. ja Vakkuri, J. (toim.) Strateginen johtaminen korkeakouluissa: Ajattelutavat, mahdollisuudet ja haasteet. Tampereen Yliopisto.

SARVARY, M. (1997): Knowledge Management and Competition in the Consulting Industry. California Management Review 41, 95-107.

SHAPIRO, E.C., ECCLES, R.G. ja SOSKE, T.L. (1993): Consulting: Has the Solution Become Part of the Problem? Sloan Management Review, Summer, 89-95.

STURDY, A. (1997): The Consultancy Process - An Insecure Business? Journal of Management Studies 34, 389-413.

STÅHLE, P. ja GRÖNROOS, M. (1999): Knowledge Management: tietopääoma yrityksen kilpailutekijänä. Helsinki: WSOY.

TAINIO, R. ja VALPOLA, A. (toim.) (1996): Johtajana muutoksissa - kokemuksia ja näkemyksiä liikeelämästä. Porvoo: WSOY.

TAYLOR, F.W. (1911): The Principles of Scientific Management. New York: Harper.

TIENARI, J. (1999): Sotakorvaustyön tehostamisesta sähköisen liiketoiminnan kehittämiseen: liikkeenjohdon konsultoinnin lyhyt historia Suomessa. Lappeenrannan teknillinen korkeakoulu, kauppatieteiden osaston tutkimuksia 1.

\section{Viitteet}

1 Englanninkielessä käytetty sana fad - suomennettuna muotihulluus, vimma, lempiajatus ja/tai keppihevonen - kuvaa tätä konsultointityön populistista puolta rikkaammin kuin sana muoti. On kuitenkin syytä tähdentää, että "otsikkojen myyminen" on vain yksi osa konsultointityötä. Kuten tässä artikke- lissa jäljempänä esitetään, konsultit saavat yleensä asiakasorganisaatioissaan aikaan jotain "todellista".

2 Tässä artikkelissa liikkeenjohdon konsulteilla tarkoitetaan suuria kansainvälisiä - lähes poikkeuksetta yhdysvaltalaisia - "megatoimistoja". Näiden toimistojen toiminta eroaa esimerkiksi konsultoinnin "pienistä erityisosaajista" (Tienari 1999; vrt. Kyrö 2000). Suuruus viittaa tässä toiminnan volyymiin ja maantieteelliseen levinneisyyteen.

3 Bruno Latour (1986) puhuu tiedon kääntämisestä. Alkuperäinen idea tai oppi muuntuu levitessään, koska se saa "energiaa" jokaiselta kääntäjältään. Kyse on myös tulkinnasta. Tapoja tulkita jonkin opin, idean tai käsityksen sisältämiä merkityksiä on ainakin periaatteessa yhtä paljon kuin on tulkitsijoita. Myös nyt käsillä olevan artikkelin esittämät ajatukset liikkeenjohdollisista opeista ja muodeista tulevat siis luetuksi ja tulkituksi monin eri tavoin. Mikään yksittäinen luenta ei ole lähtökohtaisesti toista parempi.

$\triangle$ Konsultit siis ennen kaikkea siirtävät tietoa siel4 tä, missä se on tunnettua sinne, missä se on uutta ja käyttökelpoista (Hargadon 1998; vrt. esim. Ainako ja Tienari 2000).

5 Riippuvuudella tarkoitetaan tässä eri asiaa kuin $\mathcal{S}$ edellä mainitulla "marionettiteorialla". Riippuvuussuhde toimeksiantajan ja konsultin välillä on yleensä molemminpuolinen (Sturdy 1997).

6 Tämä lainaus löytyy kahden The Economist -leh6 den toimittajan, John Micklethwaitin ja Adrian Woolridgen, liikkeenjohdollisia muoteja ja niiden levittäjiä käsittelevän kirjan The Witch Doctors (1997) johdannosta. Micklethwait ja Woolridge esittävät tapausesimerkkien avulla liikkeenjohdollisen muotiteollisuuden raadollisuuden. Heidän teoksensa on provosoiva "opas", joka on suunnattu erityisesti oppien ja muotien potentiaaliselle asiakaskunnalle.

7 Konsultointiyritysten toimintatapoihin on perinteisesti kuulunut salaperäisyys. Tämä johtuu konsultointityön luonteesta. Konsultointisuhde perustuu luottamukseen ja luottamuksellisuuteen. Asiakkaan liikesalaisuuksiin liittyvän informaation levittäminen on vastoin alan eettistä perustaa. Lisäksi esimerkiksi mainonnan käyttäminen oli pitkään vastoin alan vakiintuneita käytäntöjä. Nykyisin näkyvyys - mainokset, kommentit tiedotusvälineissä, bestsellerit jne. - on olennainen osa monien suurten konsultointitoimistojen strategiaa. Kyse on tällöin nimenomaan oman edelläkävijäbrandin luomisesta. Asiakkaista nostetaan esiin vain malliesimerkit, konsulttien ja asiakkaiden yhteistä hyötyä tavoitellen.

Q Peters ja Waterman nostivat kovien S:ien (struc8 ture, strategy, systems) rinnalle pehmeät $S: t$ (mm. skills ja shared values). Yritys- ja organisaatiokulttuurin käsitteet olivat tietenkin esiintyneet organisaatio- ja liikkeenjohtokirjallisuudessa jo hyvän aikaa ennen Petersin ja Watermanin läpimurtoa. Kulttuurin käsite lainattiin tähän kirjallisuuteen alun perin antropologiasta (ks. esim. Alvesson ja Berg 1992). 
Deal ja Kennedy (1984) korostivat 1980-luvun alkuvuosina vahvan yrityskulttuurin merkitystä vielä Petersia ja Watermania selvemmin. On syytä muistaa, että 1980-luvun alkupuoli oli länsimaisissa yrityksissä ja julkisen sektorin organisaatioissa myös esimerkiksi laatuajattelun nousun aikaa (ks. Kieser 1997; Lillrank 1998).

O Micklethwait ja Woolridge (1997) tarjoavat "ark$Y$ kigurun" titteliä Peter F. Druckerille, joka on 1940-luvulta lähtien muovannut modernia ajattelua liikkeenjohdosta.

10 Esimerkiksi Tom Petersin esiintymistekniikat ovat herättäneet myös tutkimuksellista mielenkiintoa (ks. esim. Clark ja Greatbatch 2000).

11 Käsitteellinen ero datan, informaation ja tiedon välillä on ikuisuuskysymys. Datan voidaan ajatella olevan tietoa raakamuodossaan. Kun se jäsennellään, se muuntuu informaatioksi. Kun informaatioon liitetään konteksti ja tulkinta, siitä muodostuu tietoa.

12 Eri tyyppiset konsultointiyritykset johtavat tietoa eri tavoin. Perinteiset strategiakonsultit kuten McKinsey \& Co ja Boston Consulting Group ovat yleensä luottaneet varsin "personoituun" tiedon välittämiseen. Operatiiviseen- ja tietotekniikkakonsultointiin perustansa rakentavat toimistot kuten $A n$ dersen Consulting ja Ernst \& Young "kodifioivat" monimutkaisia tiedonjyväsiä nopeasti käsiteltävään muotoon ja laajoiksi tietokannoiksi. Nyt käsillä olevan teeman kannalta tämä jälkimmäinen tapa on erityisen kiintoisa. (Ks. esim. Hansen et al 1999; Lahti ja Beyerlein 2000)
13 Andersen Consulting nousi 1990-luvun jälkimmäisellä puoliskolla suurimmaksi konsultointiyritykseksi Suomen markkinoilla. Sen menestys on perustunut ajoitukseen ja edelläkävijän aseman hyväksikäyttöön. Andersen Consultingilla oli Suomessa ensimmäisten joukossa "paketti kasassa" laajojen BPR-hankkeiden läpiviemiseksi. Se siirtyi sittemmin joustavasti BPR-hankkeista suuriin muutosohjelmiin ja edelleen myös esimerkiksi verkkoliiketoiminnan konsultointiin. Nykyisin Andersen Consulting on lisäksi mukana nousevien internetyhtiöiden toiminnassa, muun muassa ottamalla konsulttipalkkionsa omistusosuutena. Andersen Consultingin toiminta on hyvä esimerkki liikkeenjohdon konsultoinnin rajojen hämärtymisestä: tässä esimerkissä on kyse konsultointityön ja venture capital -toiminnan sekoittumisesta. (Ks. esim. Talouselämä 9/2000 \& 15/2000; Tienari 1999; Ainamo ja Tienari 2000)

14 Esimerkiksi ylimmän johdon strategiakonsul14 toinnilla ainutlaatuisen maineensa luonut McKinsey \& Co on perinteisesti ilmoittanut pysyvänsä erossa liikkeenjohdollisista "ismeistä”. Tämä retorinen linja pätee nykyisin yhä enemmän myös vaikutusvaltaisiin, operatiiviseen- ja tietotekniikkakonsultointiin perustansa rakentaviin "megatoimistoihin". (Ks. esim. Bartlett 1997

15 Kuten yllä tuotiin esille, "oivallukset" ovat 1 varsin harvoin ainutlaatuisia. Mahdollisten oivallusten kirjo on sidottu aikaan ja paikkaan. Paikka ei tässä viittaa fyysiseen tilaan, vaan kullakin hetkellä mahdolliseen oivaltajien elinpiiriin. Liikkeenjohtajien työssä oivalluksia sanelevat järkiperäisyyden ja edistyksellisyyden vaateet. Oivalluksia sävyttää myös matkiminen. Lisäksi voidaan väittää, että joku on yleensä tehnyt kyseessä olevan oivalluksen jo aikaisemmin (vrt. Bourdieu 1996).

Artikkeli saapui toimitukseen 3.8.2000. Se hyväksyttiin julkaistavaksi 31.8.2000. 